\title{
The Impact of Privatization of IDBI Bank in Indian Economy
}

\author{
Vishal Kumar ${ }^{1 *}$, Soumak Ganguly ${ }^{2}$, Payal Ghosh ${ }^{3}$, Manisha Pal $^{4}$ \\ ${ }^{1,2,3,4}$ BBA Student, Department of Management, Institute of Engineering and Management, Kolkata, India \\ *Corresponding author: raj412vishal@gmail.com
}

\begin{abstract}
Privatization refers to the public shares and Assets which are sold to the private sector in the economy. It decreases the power of government control and creates the other policies method. Privatization leads to cutting short the capital and revenue expenditure, which leads to an increase in share value in the market. During the pre-privatization period, the government used to pay less amounts of dividends to its shareholders due to its complex cost structure. Privatization leads to cutting short the capital and revenue expenditure, which leads to an increase in share value in the market. It also gave information about Public and Private sector banks. Our objective is to compare the pre and post-privatization performance like other banks of developing countries shows that privatization resulted in significant gains in profitability and efficiency. To evaluate the impact of privatization in the Indian banking sector and the relationship between privatization and Indian Economic growth by using a case study of IDBI bank condition of Indian private sector banks is analyzed using the financial statement of IDBI Bank with the help of different research methodologies.
\end{abstract}

Keywords: IDBI bank, Indian economy, Privatization.

\section{Introduction}

Privatization means to change from public to private ownership or control or transfer of assets and service functions from the public to private hands. In a competitive market, privatization had created efficiency i.e., an Allocative efficiency and productive efficiency. Allocative efficiency means the use of resources according to the demand of consumers to the production of goods and services. Productive efficiency means the use of resources at the lowest possible cost for the products.

Privatization was still a controversial matter throughout the last decade. Though the different economic theories clear out the main difference between the privatized firm and nationalized firm. In this paper, we want to show that modern and alternative strategy to privatization. In this paper, we want to show the structural difference between the governance structure and policies. We depicted the method through which Indian firms are privatized. What is the main reason behind which the privatized firms earn more revenue than a nationalized firm? We also find out why the government does not introduce a modern technique. We want to show how the other competing nationalized firms affect.

The effect of Privatization in the banking sector gives higher emergence of loans and investments. It increases the performance of the work after obtaining a target. According to [18]. After Privatization, 28\% of the performances are intensified. So, the research gives evidence of the positive and negative impact of privatization.

In recent days, a bad debt problem was very common in our daily life. This problem was not only faced by private sector banks, but public sector banks are also facing the same problem. With the increase in the bad loan, liabilities were also increased. A common phenomenon among lenders with the inclusion of the private sector to generate demand for the politicians and grant loans for the dubious borrowers often with a credit history which is poor and Bad debts simply rolled over years after years with no resolution from the bank side. At last bank and RBI take some serious steps. Bank Started taking the defaulters asset and auctioned it to the other firm so that some money recovered from that asset. Due to this bad debt problem, the banking sector cannot reach up to its projected growth.

Industrial Development Bank of India (IDBI Bank Limited or IDBI Bank or IDBI) was established in 1964 by an Act of Parliament to provide credit and other financial facilities for the development of the fledgling Indian industry. IDBI was established in 1964. Many reputed financial Institutions like SIDBI, Exim Bank, NSE, and NSDL find their roots in IDBI. Finally, during September 2004 RBI incorporated IDBI as a scheduled bank. Subsequently in January 2019 Life Insurance Corporation of India (LIC) completed the acquisition of a $51 \%$ stake of IDBI Bank after obtaining a green signal from the Insurance Regulatory and Development Authority of India. (IRDAI) and thus RBI has categorized it as a private sector bank.

After that sea change in the operating method was observed in IDBI as the power had decreased. Some new products are introduced for-profit motive; it opened for Foreign Direct investment and helps the country to develop a strong economy. It has been proved post-privatization the instructions are earning more profit than the existing PSUs due to the cutting short of capital and revenue expenditure, which leads to the increase in share volume in the market.

Many findings stated that privatization did not help to improve the Indian economic growth but helped to reduce inflation, inequality. On the other hand, many economists 
demonstrated that the disinvestment process helped in economic growth. Privatization shows many theoretical economic benefits that are usually taken by the countries to reduce government interference. And, also privatization leads to the creation of the free market which leads to the power of taking individual decisions and this helps to provide financial relief and boost self-ownerships. Privatization also has a positive effect on the fiscal situation of a country as privatization helps to pay off the debts and this process helps the government by paying off taxes and thus decreases the borrowings and debts of the country. Loss-making private sector undertakings in India show a negative impact in the Indian economy so to bring it in stable form public sector undertakings are transferred to private hands.

\section{Literature Review}

According to [5] Privatization refers to the transfer of ownership, which includes the shares and assets transfer from the government's custody to the private owner's custody. They innovate the product to make it profit-oriented and thus the impact observed in the change of FDI policy and helps in the Economic growth, due to the increase of competition in the market.

In the book of [16] privatization is the structure of the government activities to streamline the activities of the public sector, which helps PSU to face global and domestic challenges in the competitive market.

[23] Privatization in the poorer country brings a supernatural impact in front of the countryman. Privatization makes new owners richer in society. According to him, privatization is good for the economy of the country. As the private sector is considered being more definitive and they are more selfmotivated for their quality of product and services. This will increase the competitiveness of the market and help PSU to rig out the loan and debts of the PSU's. Private firms earn more profit due to their customer-centric approach. The private sector leads to a focus on profit maximization rather than the uplifting of the weaker section of the society.

It is defined in the article of [12] Public sector banks and Private sector banks have lots of different and very basic differences: the public sector banks owned by the government and private sector banks fully owned by the owner of the bank.

[26] Tried to analyze a comparison between the performance of the public and private sector banks, by using statistical tools where it shows that the number of banks and offices increases. Credit deposit ratio increases significantly whereas non-profit assets decrease from $7.3 \%$ to $1.7 \%$.

[19] New private sector banks must follow the new guidelines of RBI bank, where the bank must maintain a minimum paid-up capital of Rs. 100 Crores within 3 years and raise its paid-up capital up to Rs. 300 Crores.

In the article of [11] Banks finance small businesses lending them in various ways. Once funded the small business may begin to operate and begin on a growth plan. Banks also help in funding the government spending by purchasing bonds issued by 'The Department of the treasury' both long term and short term. Capital Formation was increased by the bank by collecting deposits and converting it into loan advances to industries.

[9] In the paper it has evaluated the financial performance between research paper it wanted to show whether Dena Bank leads or lags the other comparative Dena Bank and five other reputed banks (SBI, BOB, PNB, IDBI, and Canara Bank). By these banks considering 3 successive years starting from 201416. So now the analysis shows the IDBI Bank.

[8] The 'political theorists' against the government and said that ownership shows misallocation of the resources and inefficiencies of the public enterprise and there is the political motive behind the ownership. It is in the argument that Privatized firms are better in performance and it is more efficient at work. However, the staff opposition raises questions in the performance and efficiency of the PSBs, who increase the capital before the extra reduction in the stake which is allowed.

To assess the impact of privatization of the banking sector on the growth we first need to examine how the sector enhances its productivity and efficiency, and how this is transmitted to improvements in growth in the productive sectors of the economy. Generally, as an economy grows and develops, the banking sector becomes more specialized, sophisticated, and cost-effective. In this growing financial depth and financial efficiency gives constructive feedback on capital accumulation, productivity, and growth. It has been noted that it is the design of developed countries. It is not replicated to the near extent and intensifies in the developing countries.

[17] In principle, privatization need not affect the stock of wealth in an economy, nor its distribution. States hold firms are public assets through which the owner earned a return. Provided the assets to be privatized are valued in such a way that their price represents the discounted sum of the profits to be earned from them. The impact on the distribution of privatization depends on how the ownership of the assets is distributed into private hands; both the pricing and to whom the SOEs are privatized. In extreme cases when assets are transferred by vouchers to each citizen equally from the state to private hands at a zero or nominal price, as in the Czech Republic, there is a transfer from public to private assets equal to the value of the privatized.

A "caution approach" is dynamic and tends to blunt the effectiveness of the privatization. The important role played by PSEs in the economic and social development of Indian economy; this has been stated that PSEs serve the best public interest by fulfilling all the desired financial and economic obligations as per the government's plans and perspectives, since, an increase in financial profitability is neither a necessary nor a sufficient condition for the enhancement of society's wellbeing; they have opined to devise a policy which simultaneously fulfills both the social and commercial needs.

It has been evident from several studies that countries with 
no current unemployment are exposed to clobbering of job insecurity and redundancy. However, particularly at a time of jobless growth and even "job-loss" growth, privatization typically is associated with reduction and reorganization of the labor force, either in preparation for privatization or soon afterward. Moreover, even where expansion and investment can be expected to absorb labor and even facilitate the growth of the labor force in the long term, there is frequently a short-term decline.

In the Paper of the [4] at analyzing the relationship between a non-performing asset (NPA) and gross domestic product (GDP) that is it tried to show an impact on GDP when NPA is changing. The paper concludes that by hypothesis testing there is a positive relation between NPA and GDP. Under linear Regression Analysis represents the simple correlation between the Independent Variable (NPA) and Dependent Variable (GDP).

\section{Objectives}

- To evaluate the impact of privatization in the Indian banking sector.

- To find out the relationship between privatization and Indian Economic growth.

- To Study the impact of disinvestment and comparison between pre- and post-disinvestment of IDBI Bank.

\section{Research Methodology}

The various research methodologies or tools which were used in the project, for the analysis, calculation, and data interpretation required as under:

\section{A. Presentation of the collected data}

- All data are Secondary Data.

- For depicting the detailed information about the Bank with its credit ratings and the financial statements with annual reports. "MS EXCEL GRAPH" was used for the graphical representation of the data.

\begin{tabular}{|c|c|c|c|c|c|}
\hline \multirow{3}{*}{ NET PROFIT } & & $\mathbf{N}$ & Mean & Std Deviation & Std Frror Mean \\
\hline & PRE-DISINVESTMENT & 15 & 0.114 & 0.05482 & 0.01415 \\
\hline & POST-DISINVESTMENT & 4 & 0.0734 & 0.02189 & 0.01095 \\
\hline \multicolumn{6}{|l|}{ RETURN ON ASSET } \\
\hline & PRE-DISINVESTMENT & 15 & -0.0214 & 0.02138 & 0.00552 \\
\hline & POST-DISINVESTMENT & 4 & -0.0318 & 0.05317 & 0.02659 \\
\hline \multicolumn{6}{|l|}{ CAPITAL ADEQUACY RATIO } \\
\hline & PRE-DISINVESTMENT & 15 & 0.1104 & 0.0173 & 0.00447 \\
\hline & POST-DISINVESTMENT & 4 & 0.1107 & 0.01991 & 0.00996 \\
\hline
\end{tabular}

Table 2

\begin{tabular}{|c|c|c|c|c|c|c|c|}
\hline \multicolumn{2}{|l|}{ SAMPLE T- TEST } & \multirow[t]{2}{*}{$\mathbf{T}$} & \multirow[t]{2}{*}{ df } & \multirow[t]{2}{*}{ Sig. (2-tailed) } & \multirow[t]{2}{*}{ Mean difference } & \multicolumn{2}{|c|}{ 95\% Confidence Interval of the difference } \\
\hline & & & & & & LOWER & UPPER \\
\hline \multirow[t]{2}{*}{ NET PROFIT } & PRE-DISINVESTMENT & 8.053 & 14 & 0 & 0.11398 & 0.0836 & 0.1443 \\
\hline & $\begin{array}{l}\text { POST DISINVESTMENT } \\
\end{array}$ & 6.703 & 3 & 0.007 & 0.07338 & 0.0385 & 0.1082 \\
\hline \multirow[t]{2}{*}{ RETURN ON ASSET } & PRE-DISINVESTMENT & -3.869 & 14 & 0.002 & -0.02136 & -0.0332 & -0.0095 \\
\hline & POST DISINVESTMENT & -1.197 & 3 & 0.317 & -0.03182 & -0.1164 & 0.0528 \\
\hline \multirow{2}{*}{$\begin{array}{l}\text { CAPITAL } \\
\text { ADEQUACY RATIO }\end{array}$} & PRE-DISINVESTMENT & 24.727 & 14 & 0 & 0.11043 & 0.1009 & 0.12 \\
\hline & POST DISINVESTMENT & 11.115 & 3 & 0.002 & 0.11065 & 0.079 & 0.1423 \\
\hline
\end{tabular}

B. For analysis

- For analyzing a relation between NPA of the bank GDP, and Inflation Rate "COMPARATIVE ANALYSIS METHOD” is used.

- For the analysis of the increase and decrease of Return on capital employed, return on assets, Operating Profit Margin, and Net Profit Margin "COMPARATIVE ANALYSIS METHOD” is used.

\section{For calculation}

- For Testing Financial Stability and Risk Analysis "Hypothesis testing (t-test) is used".

- One sample T-test using quarterly data for the last five years.

- To find out the relation between Net NPA, GDP, and

D. Graphs

The bar diagram is used for depicting the profitability of IDBI bank.

- The column graph is used for depicting the stability of IDBI bank.

\section{Analysis}

\section{STABILITY GRAPH OF IDBI BANK}

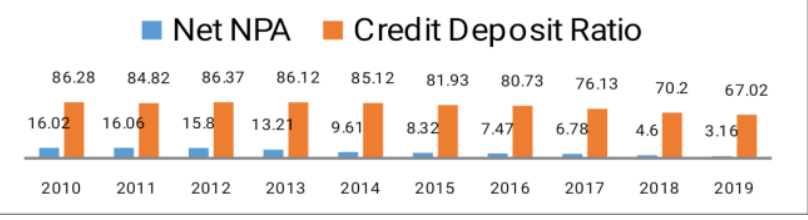

Fig. 1. Stability graph of the IDBI bank Inflation Rate Correlation Analysis is used. 
Table 3

\begin{tabular}{|c|c|c|c|c|c|}
\hline \multicolumn{6}{|c|}{ Spearman's Correlations } \\
\hline & & & NET_NPA & GDP & INFLATION_RATE \\
\hline \multirow[t]{10}{*}{ Spearman's rho } & & & & & \\
\hline & \multirow[t]{3}{*}{ NET_NPA } & Correlation Coefficient & 1.000 & .134 & $.952^{* *}$ \\
\hline & & Sig. (2-tailed) & & .713 & .000 \\
\hline & & $\mathrm{N}$ & 10 & 10 & 10 \\
\hline & \multirow[t]{3}{*}{ GDP } & Correlation Coefficient & .134 & 1.000 & .255 \\
\hline & & Sig. (2-tailed) & .713 & - & .476 \\
\hline & & $\mathrm{N}$ & 10 & 10 & 10 \\
\hline & \multirow[t]{3}{*}{ INFLATION_RATE } & Correlation Coefficient & $.952^{* *}$ & .255 & 1.000 \\
\hline & & Sig. (2-tailed) & .000 & .476 & \\
\hline & & $\mathrm{N}$ & 10 & 10 & 10 \\
\hline 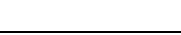 & & & & & \\
\hline
\end{tabular}

\section{PROFITABILITY GRAPH} OF IDBI BANK

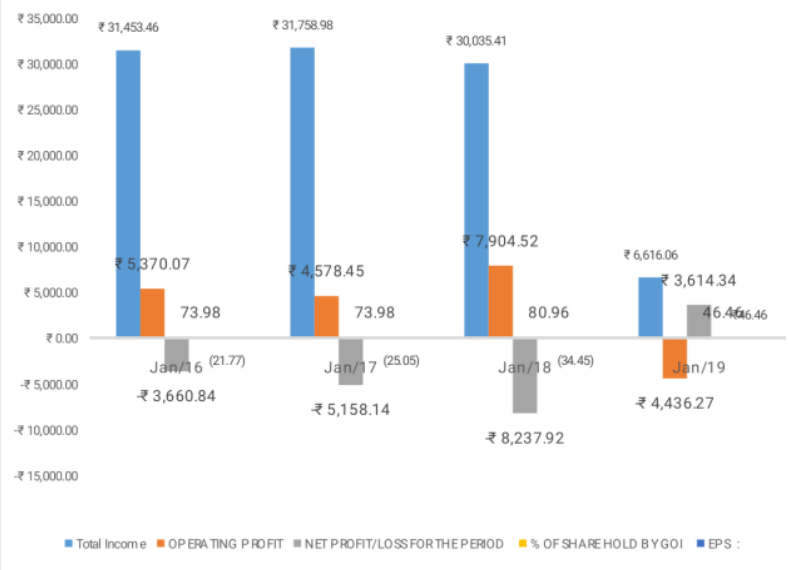

Fig. 2. Profitability graph of IDBI bank

\section{Findings}

- After a detailed Qualitative analysis of different literature reviews of Privatization and Indian Banking System this study discovers the following findings:

1. Private Ownership improves the efficiency of the Banks.

2. It has been observed that partially privatized banks perform better than public sector banks in the terms of efficiency and financial performance.

3. Indian partial Privatization appeared to have resulted in positive outcomes.

4. Privatization provides benefits such as improved access to external resources as Creditors and it is perceived that privatized banks are more creditworthy than state-owned banks.

- After detailed Ratios and Profit Analysis from IDBI Bank's financial statement, the study discovers the following findings:

1. The examination of Profitability Ratio through One-
Sample t-test shows that there is a significant change in Net Profit and Return on Assets post disinvestment and also on the other hand there is a significant increase in Capital Adequacy Ratio (CAR) post disinvestment shown in table 2.

2. From the One-Sample t-test analysis, we observe that IDBI Bank's calculated value of Net Profit, Return on Assets (ROA) and Capital Adequacy Ratio (CAR) are more than the table value hence Null Hypothesis is rejected, and Alternatives Hypothesis is accepted.

- After a detailed analysis of Net Non-Performing Assets of IDBI Bank with Gross Domestic Product (GDP) and Inflation Rate, this study discovers the following findings:

1. Correlation Analysis is significant at 0.01 levels shown in table 3, between Net Non-Performing Assets (NPA) and Gross Domestic Product (GDP) which results in 0.134 and suggests that there is the only simple correction.

2. Correlation is Significant at 0.01 levels, between Net Non-Performing Assets (NPA) and Inflation Rate which resulted in 0.972 shown in table 3 and suggests that there is Perfect Positive Correlation.

\section{References}

[1] https://taxguru.in/finance/mrtp-act-repealed-and-is-replaced-by-thecompetition-act-2002-with-effect-from-september-1-2009.html. [Accessed 03 September 2009].

[2] Investing.com, [Online]. Available: https://in.investing.com/currencies/usd-inr-historicaldata?end_date $=1577817000 \&$ interval_sec $=$ monthly\&st_date $=14200506$ 00 .

[3] Worldwide Inflation Data, [Online]. Available: https://www.inflation.eu/inflation-rates/india/historic-inflation/cpiinflation-india.aspx.

[4] N. M. Aisac, H. Elizabeth Mathew and S. Cherian, "The Rising Level of NPAs and Its Impact on GDP of India," in Journal of Emerging Technologies and Innovative Research, vol. 5, no. 11, November 2018.

[5] A. Coskun Can, "An Introduction to the Theory of Privatization," in The Journal of Social, Political and Economic Studies, vol. 20, no. 2, pp. 187217, 1995.

[6] M. K. Rastogi and S. K. Shukla, "Challenges and Impact of Disinvestment on Indian Economy," in International Journal of Management \& Business Studies, vol. 3, no. 4, pp. 44-53, December 2013. 
[7] S. Estrin and A. Pelletier, "Privatization in Developing Countries: What are the lessons of recent experience?" in EPS PEAKS, pp. 1-50, November 2015.

[8] A. Filipovic, "Impact of Privatization on Economic Growth," in Undergraduate Economic Review, vol. 2, no. 1, pp. 1-36, 2006

[9] A. Haldankar and D. Kumar, "A Comparative Study of Financial Performance of Dena Bank and Five Leading Indian Banks," in The Management Quest, vol. 1, no. 1, pp. 01-22, April-September 2018.

[10] M. Haque, Privatization or Reform: Public Enterprise Management in Transition, Greenwood: Greenwood Press, 2000, pp. 217-238.

[11] B. Kalpana and T. V. Rao, "Role of Commercial Bank in the Economic Development of India," in International Journal of Management and Applied Science, vol. 3, no. 4, pp. 1-4, 2017.

[12] A. Kaur Hundal and M. Singh, "Performance Evaluation of Public and Private Sector Banks in India: A Comparative Study," in Paripex: Indian Journal of Research, vol. 5, no. 4, pp. 237-242, April 2016.

[13] G. Mackenzie, "The Macroeconomic Impact of Privatization," in International Monetary Fund, vol. 45, no. 2, June 1998.

[14] A. K. Makhija, "Privatization in India," in Economic \& Political Weekly, vol. 41, no. 20, pp. 1947-1951, 20 May 2006.

[15] S. Mittal, "Positive Impact of Privatization on Indian Economy," in International Journal of Advanced Research and Development, vol. 3, no. 7, pp. 110-113, 2018

[16] T. Mohan, "Privatization in India," in Privatization in India - Challenging Economic Orthodoxy, $1^{\text {st }}$ ed., London, Taylor and Francis, 2005, pp. 01240.
[17] T. Piketty, "Capital is Back: Income Ratio in Rich Countries 1700-2010," in The Quarterly Journals of Economics, vol. 129, no. 3, pp. 1255-1310, August 2014.

[18] M. Ranjan Babu and A. Kumar M, "Evaluating The Nationalization \& Privatization effect: A Case of Indian Banking Industry," in Banks and Bank System, vol. 13, no. 1, pp. 11-21, 2nd January 2018.

[19] K. Ranju, "Impact of Privatization on Indian Banking Sector," in International Journal of Advanced Trends in Engineering and Technology, vol. 1, no. 1, pp. 105-107, 2016.

[20] M. Sathya, "Privatization, Performance, and Efficiency: A Study of Indian Banks," in VIKALPA, vol. 30, no. 1, pp. 7-16, January 2005.

[21] K. M. Schmidt, "The Costs and Benefits of Privatization: An Incomplete Contracts Approach," in The Journal of Law, Economics, \& Organization, vol. 12, no. 1, 2016.

[22] J. Selvam, "Privatization In India: Is It Justified?," in Indian Journal of Economics \& Business, vol. 8, no. 1, pp. 69-78, 2009.

[23] A. K. Singh and T. Kumar, "Advantages and Disadvantages of Privatisation in India," in International Journal of Advanced System and Social Engineering Research, vol. 3, no. 1, January 2013.

[24] P. Trivedi, "What is India's Privatization Policy," in Economic and Political Weekly, pp. M71-M76, 1993.

[25] J. Vali, "Employment and Labour Markets in Transitional Asian Economics," in ILO, 1996.

[26] D. K. Vishwakarma and D. K. Sharma, "Performance of Indian Public and Private Sector Banks- A Comparative Study," in International Journal of Advance and Research, vol. 2, no. 10, pp. 532-536, 2014.

[27] "Wikipedia," [Online]. Available: www.wikipedia.com. 